\title{
Investigation of the Relationship Between Dispositional Flow State, Sensation Seeking and Ski Resort Preference of Skiing and Snowboarding Participants
}

\author{
Sırrı Cem Dinç ${ }^{1} \&$ Mustafa Demircan ${ }^{2}$ \\ ${ }^{1}$ School of Sport Sciences and Technology, Nevşehir Hacı Bektaş Veli University, Nevşehir, Turkey \\ ${ }^{2}$ Social Sciences Institute Department of Recreation (Ms), Manisa Celal Bayar University, Turkey \\ Correspondance: Sırrı Cem Dinç, Nevşehir Hacı Bektaş Veli University, School of Sport Sciences and \\ Technology, 2000 Evler Mah. Damat İbrahim Paşaa Kampüsü H Blok, Nevşehir, Turkey. E-mail: \\ scem.dinc@gmail.com
}

Received: July 10, 2019

Accepted: August 8, 2019 Online Published: September 19, 2019

doi:10.5539/jel.v8n5p57

URL: https://doi.org/10.5539/jel.v8n5p57

\begin{abstract}
The aim of this study is to investigate the relationship between was to examine dispositional flow state, sensation seeking and ski resort preference of skiing and snowboarding participants. The sample of this study constituted 510 ( 126 female $\bar{x}=23.94 \pm 5.79$ years; 384 male $\bar{x}=27.33 \pm 7.87$ years) skiers and snowboarders from varied ski resort between the years 2018-2019. A demographic questionnaire, The Contextual Sensation Seeking Questionnaire for Skiing and Snowboarding (CSSQ-S) Ski Resort Preference Scale (SRPS) and Dispositional Flow Scale-2-Short Form (DFS2-SF) were used to collect data. Before the statistical analysis, coefficient of kurtosis, coefficient of skewness and test of normality (Kolmogorov-Smirnov Test) of the data were examined and the deviation from the normal distribution was determined meaningless $(p>.05)$. Pearson Product-Moment Correlation Coefficient was used to determine the relationship between variables. The mediator effect of sensation seeking in the relationship between ski resort preference and flow of participants were examined with Structural Equation Modeling (SEM). The correlation value between the variables was determined between $0.196-0.549$. ( $(\mathrm{P}<0.01)$. There is causal relationship between; SRPS and DFS2-SF $(\beta=.187, \mathrm{p}<.01)$, SRPS and CSSQ-S $(\beta=.932, \mathrm{p}<.01)$, CSSQ-S and DFS2-SF $(\beta=.581, \mathrm{p}<.01)$ respectively. It was found that when SRPS variable was included in the model as a mediating variable, causal relationship between SRPS and DFS2-SF was eliminated $(\beta=7.067, p>.05)$ and causal relationship between CSSQ-S and DFS2-SF was significantly increased $(\beta=.722, \mathrm{p}<.01)$. When the fit indexes of the models were examined, all values in all four models indicated acceptable/perfect fit. The results show that ski resort preference has a significant causal relationship on flow state and sensation seeking in skier and snowboarders. However, when sensation seeking is included in the model as a mediating factor, effect of the ski resort preference on the flow state disappears, while the effect level of sensation seeking increases.
\end{abstract}

Keywords: skiing, snowboarding, sensation seeking, flow, service quality

\section{Introduction}

\subsection{Skiing and Snowboarding as an Outdoor Adventure Activities.}

In the last 20 years, participation in adventure sports and outdoor sports has increased substantially compared to traditional sports (Pain \& Pain, 2005). There are studies revealing that the participation of the individual, who is in interaction with nature, in adventure sports can have positive psychological and emotional outcomes such as courage, development of humility and benefits of feeling fear (Brymer \& Oades, 2009; Willig, 2008). Puchan (2004) expressed adventure sports as activities that have short-lasting effects but leave a mark in time. Adventure and outdoor sports provide excitement to participants while at the same time requiring taking risks (Şimşek, 2012). Studies show that participants of high-risk sports report higher Sensation Seeking levels compared to non-participants (Thomson \& Carlson, 2014).

High-risk adventure sports are defined as activities that can cause serious injury or death (Willig, 2008). According to Mitchell (1983), adventure experience consists of a set of activities that are in concordance with personal mood, that motivate participants internally and involve uncertainty, in which participation is based on free will (Priest \& 
Gass, 2017). In his study where he listed high-risk adventure sports according to the risks involved and examined the views of participants towards taking part in these activities, Pedersen (1997) ranked the activities according to their risk perception levels. He rated activities such as base jumping, skydiving, mountain climbing (high altitude, rock climbing, mountaineering), bungee jumping, whitewater kayaking and skiing, snowboarding and skiing, paragliding, hang-gliding, and scuba diving among high-risk adventure sports. In addition to those listed above, it was seen that in his study titled the perception of the risk towards outdoor sports, Demirhan (2003) added sports such as orienteering, trekking, mountain biking, rafting, sailing, and windsurfing and placed the activities into the land, air, water, winter and motorsports categories. Finally, Thomson (2013) included sports such as BMX, cave diving, kitesurfing, highlining, skateboarding, aggressive inline skating and wingsuit flying in high-risk adventure activities and divided them into main categories such as gravity sports, mountain sports, and water sports. Tomlinson and Leigh (2004) grouped high-risk adventure sports as air, land and water sports. In this sense, skiing and snowboarding are two of the high-risk adventure sports that are defined within the main categories of gravity sports (Thomson, 2013) or winter sports (Demirhan, 2003). Downhill high-speed activities such as skiing and snowboarding are considered to be very risky activities that have the potential to fall and crash, which may result in serious injury (Thomson et al., 2014; Goma-i Freixanet et al., 2012; Shealy et al., 2005). Participation of individuals who are in interaction with nature in high-risk activities creates passion and excitement in them (Yavaş, 2017).

\subsection{Why People Tend to Participate Outdoor Adventure Activities: Flow State Theory}

While it cannot be clearly explained why participants tend to take high risk, it has been tried to be explained with various theories (Dinç, 2018). Psychological studies conducted associated the increase in the sense of self and sensation seeking with risk-taking behavior. These individuals are expressed as individuals who seek new experiences and satisfaction (Slanger \& Rudestam, 1997). A social-psychological perspective to the issue was presented by Ellis's (1973) concept of optimal arousal. Priest and Gass (2017) associated the state of the participant with Csikszentmihalyi and Csikszentmihalyi's (1991) concept of "flow state" and stated that the skill level, experience, risk perception, and challenge levels presented to the individual by natural environments were related to the concept of optimal arousal. An insufficient skill or an excessively challenge level means that the adventure activity in question cannot be achieved.

Flow state is regarded as the theory of flow state in various written sources (Csikszentmihalyi, 1990; Weinberg $\&$ Gould, 2003). Flow means feeling an activity to the maximum while engaging in it with a focused state of concentration. As a positive experiential state, The Flow take place when the performer is totally connected to their performance, in a situation where personal skills equal required challenges. It is a state aspired to by not only elite athletes (Jackson, 1992), but also any level of sport participants who may be enjoyed participation. (Csikszentmihalyi, 1992; Jackson \& March, 1996). In theory, flow as a mental state was expected to show optimal sportive performance as well as presenting an optimal experience. In the general view, flow is seen as the status of peak performance (Jackson et al., 2001). Based on the interviews he conducted, Csikszentmihalyi defined flow state as the most suitable psychological condition emerging as a result of the balance between the perceived difficulties and skills in an activity (Csikszentmihalyi, 1990; Jackson \& Eklund, 2004). When the factors necessary for flow state to be formed and the ones that interrupt it are considered, it can be said that the participant's ability to realize the experience of the activity and the service centers that include the area where the sport is performed are directly proportional to each other (Harrison \& Chalip, 2005).

\subsection{Why People Tend to Participate Outdoor Adventure Activities: Sensation Seeking}

Another perspective to explain why participants tend to take high risk is also sensation seeking. Although high-risk sports include the potential of serious injury or death, some individuals view participation in these activities as sensation seeking while some others are reluctant. The personality traits and sensation seeking ways of the individuals who participate in high-risk sports are in parallel (Thomson et al., 2012). Participants constantly seek new points of adventure to achieve excitement and alleviate distress. From risk-taking perspectives, participation in extreme sports (such as skiing and snowboarding) can be considered as a pathological and unhealthy activity that results in the realization of an erratic feature and self-deception and as a hedonistic activity for excitement (Brymer, 2010). It is known that there is a relationship between sensation seeking and impulsivity and biological dispositions. Due to this, sensation seeking is a system linked to genetic structure (Zuckerman et al., 1980). Zuckerman (1979) stated that individuals have different sensation seeking needs and impulse levels, and associated sensation seeking with the courage of the individual in unusual situations. In his studies, Zuckerman (1994) defined sensation seeking as "the need for different, new, mixed emotions and experiences and the need to take physical, social, legal and financial risks for the sake of such experiences". Individuals with a high sensation seeking impulse consider the risks likely to occur in the activities 
they have not experienced before as inadequate and show a tendency to experience lower anxiety in this process. Individuals who have such expectations are more likely to participate in the activities (Zuckerman \& Kuhlman, 2000).

The search for risk-taking and sansation seeking related to skiing and snowboarding has been investigated in a series of studies (Ruedl et al., 2010; Russel et al., 2010; Cusimano \& Kwok, 2010, Thomson et al., 2013, Thomson et al., 2014, Thomson \& Carlson, 2014). Ruedl et al. (2012) showed that ski and snowboard tourists' risk-taking behaviors and sensation seeking personality traits may be related. In other words, it was emphasized that the personality trait of sensation seeking is related to risky behaviors on ski slopes. In another study of risk-taking related to skiing and snowboarding, Ruedl et al. (2010) found that individuals to take the high risk were participants who preferred to ski faster. It is suggestive of possibilities that skiers and snowboarders who prefer to take high risk prefer fast and unsafe off-piste slopes? Because Demirhan et al. (2014) stated that these sports motivate and attract participants due to their risky structures that include various activity areas, specific techniques, equipment, attitudes, and behaviors. It was also revealed that the individuals who are interested in activities of outdoor and adventure sports felt great pleasure and excitement from engaging in these activities as they interacted with nature and fulfilled their longing towards nature by watching the landscape (Mengütay, 2003). Therefore, these activities provide individuals with the opportunity to experience more diverse and exciting occasions and challenges (Jenkins \& Pigram, 2003).

Do adventure products of different difficulties that feed on the sense of sensation seeking possessed by the participant and presented in balance with skill level determine the value of the service in the eyes of the consumer? Sanchez et al. (2004) explain the value of service as comparing the relationship between the benefit and cost perceived by the participant. In this sense, it is clear that a skier receiving services from a facility will evaluate the place according to their expenses and the benefits they receive. The benefit obtained from the perspective of our study is regarded as the individual reaching the sense of optimal experience, i.e., flow, by fulfilling their various sensation seeking levels.

\subsection{The Quality of Service in Ski Resort}

What is important in making a firm or facility preferable is the high-quality service and value it provides to its guests rather than the differentiation they will implement on their products and services. Those who produce and present higher quality and value products/services compared to their competitors stand out in the competition war that has been elevated in recent years (Yücenur, 2011). Service is the set of activities or benefits presented or suggested by a group of people to others in a non-storable way to satisfy their consumption needs (Palmer, 2001). There are a great number of studies in the literature on the measurement of the value of sports services and its relationship with various variables. The Quality of Service in Ski Resorts (Gencer et al., 2008), The Motive of Consumption in Extreme Sports (Şimşek, 2010), Quality Models in Participation-Based Sports Services (Yıldız, 2009), and The Quality of Service in the Sports and Fitness Centers of Universities (Aslan \& Koçak, 2011) are some of these studies. It is stated that the quality of service arises from the comparison of perceived performance and expected performance (Grönross, 1984; Parasuraman et al., 1988), the comparison of performance according to ideal standards (Teas, 1993) or comparison of only performance-related perceptions (Cronin \& Taylor, 1992; Gençer et al., 2008). Service Quality depends on expected service meeting expectations. The most important factor that plays a determining role in the quality of service is the customers (Zeithalm \& Bitner, 2000). Quality of service can be measured with the perceptions of customers. For this reason, how quality is perceived by customers in places offering services is the most important factor (Yapraklı \& Sağlik, 2010). The issue of whether the satisfaction received from services directly influences customers to prefer the places they received services from again or gravitate towards different alternatives and what kind of interaction sensation seeking levels and the quality of time spent in the facilities where the service was provided have with the value in the eyes of the customer is unclear. While Petrick et al. (2001) stated that the sense of satisfaction after service has an effect on the values related to products and services, Cronin et al. stated the opposite opinion. From the perspective of winter sports centers that provide customer-oriented service, the sense of quality can be regarded as an important factor in terms of satisfying customers. After developing the "SERVQUAL (Service Quality)" scale in 1985, Parasuruman et al. (1985) listed various dimensions as accessibility, eagerness, courtesy, talent, honesty, communication, physical assets, trust and understandability.

When studies on winter sports are examined; factors such as customer loyalty, customer satisfaction (Alexandris, et al., 2006; Matzler et al., 2008) and customer motivation (Dolnicar \& Leisch, 2003; Matzler \& Siller, 2003) are emphasized and services offered, snow quality, entertainment, transportation, tracks, variety of ticket prices, variety of rental equipment, track facilities, and alternative accommodation fees are regarded as other important factors (Koşan, 2013). These factors can be regarded as the focal points of service quality in the field of 
management and marketing. The individual who oscillates between various alternatives in ski resorts will attempt to choose what is more advantageous for them (Cihangiroğlu \& Şahin, 2012). This choice will play an important role in understanding the reasons for consumer participation, preparing programs in the light of this information, and attracting extreme athletes to environments of extreme sports (Şimşek, 2012). It is seen that the effects of sensation seeking and the emotional status towards activities, which are pronounced among the individual characteristics of participants, on the consumption behaviors of adventure participants have not been evaluated aggregately to date. At this point, the expectations of participants towards the service they will receive, their evaluations after purchasing the service and their feelings and thoughts when choosing a facility will be important in terms of the marketing of the resort (Mucuk, 1998). Within this scope, the aim of the research is to examine the relationship between flow state and sensation seeking in the ski resort preference of individuals who engage in snowboarding and skiing.

\subsection{Study Model and Hypotheses}

In the light of literature within the study, a theoretical model was formed. In the formed model, it is thought that "sensation seeking" variable has a mediating effect. The conceptual model which is formed in relation to the study was shown in Figure 1. In the model formed related to the study, independent variable was determined as "ski resort preference", dependent variable was determined as "flow state" and mediating variable was determined as "sensation seeking".

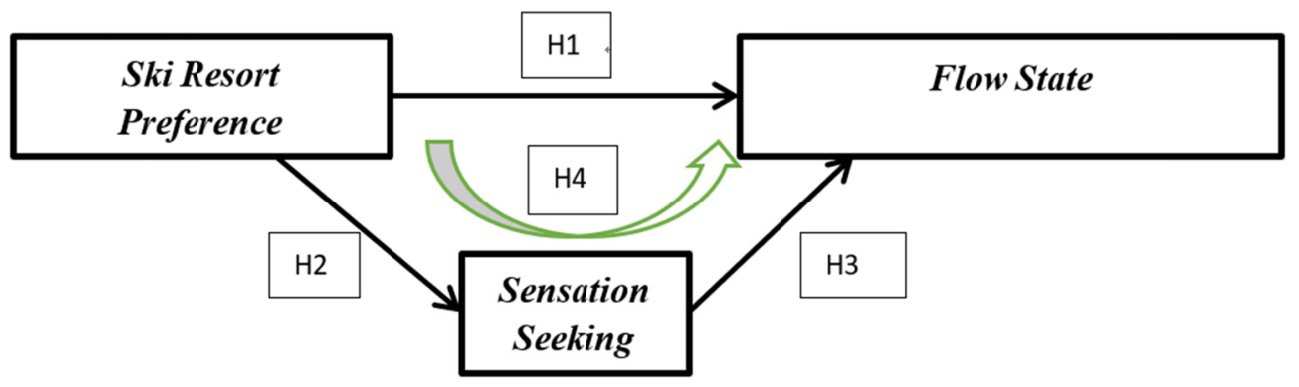

Figure 1. Model formed for ski resort preference, sensation seeking and flow state

These conditions are incorporated and listed below:

H1: The independent variable (ski resort preference) should have an effect on the dependent variable (flow state)

H2: The independent variable (ski resort preference) should have an effect on the mediator variable (sensation seeking).

H3: The mediator variable (sensation seeking) should have an effect on the dependent variable (flow state).

H4: When the mediator variable (sensation seeking) is included in the analysis, the effect of the independent variable (ski resort preference) on the dependent variable (flow state) should be reduced or eliminated completely.

Baron and Kenny (1986) is stated that if the significance, ensued after the analysis performed with the fulfillment of these conditions, was removed completely, it indicates the existence of "full mediation" relationship; only if there was a decline in the degree of relationship it shows the existence of "partial mediation" relationship.

\section{Method}

In the study descriptive and relational study models were used.

\subsection{Participants}

The study was applied to 510 ski and snowboard participants (female $126 \overline{\mathrm{x}}=23.94 \pm 5.79$ age; male $384 \overline{\mathrm{x}}=$ $27.33 \pm 7.87$ age) in total between 2018 and 2019. The data were collected by using group sampling method among skiers and snowboarders. Group sampling method is a sampling type which is used when listing a group which is used in a large-scale scanning research is hard (Balc1, 2009). 


\subsection{Data Collection Instruments}

The data collection tools used in the study consists of 2 parts. The first part is personal information form used in order to define the demographic information of ski and snowboard participants; the second part is the Contextual Sensation Seeking Questionnaire for Skiing and Snowboarding (CSSQ-S), Ski Resort Preference Scale (SRPS) and Dispositional Flow Scale-2-Short Form (DFS2-SF). The mean duration of filling out the questionnaire was about 15 minutes. Nothing was used to motivate participants; a total of 553 questionnaires were collected and 510 of them were evaluated after missing and incorrect coded items were removed from the analysis.

\subsubsection{Personal Information Form}

The personal information form prepared by the researcher was used in order to determine the demographic information of ski and snowboard participants. There are four questions asked in the personal information form including questions as sex, age, domain ability and ski track preference.

\subsubsection{Ski Resort Preference Scale (SRPS)}

Ski Resort Preference Scale (SRPS) developed by Demircan (2019) was used in the study. The scale has four subscales and 21 items, four sub-dimensions (Alternative Services, Supporting Services, Accommodation \& Ski Lift and Nature and Environment. it is also 5-point Likert type. Example items are "Variety of accommodation facilities (hotels, apartments, bungalows, pensions, etc.)" and "New and comfortable ski lifts (wind protection and heating, etc.)" for Accommodation \& Ski Lift sub-dimension; "Presence of advertisement brochure and information office in ski resort" and "The proximity of the ski resort to the airport" for Alternative Services sub-dimension; "Presence of markings (marker bars, safety barriers and signposts) around the runways" and "Presence of repair and maintenance units for individual materials in the ski resort" for Supporting Services and "Natural beauty of runway areas (forest, mountains, etc.)" for Nature and Environment sub-dimension. The scale runs in average points related to each sub-dimension. The Cronbach alpha values range between .71 and .89 . The scale represents $61 \%$ of the presented total variance.

\subsubsection{Contextual Sensation Seeking Questionnaire for Skiing and Snowboarding (CSSQ-S)}

CSSQ-S developed by Thomson (2012) and adapted into Turkish by Dinç and Demircan (2019) was used in the study. Turkish Version of CSSQ-S comprises 9 items, anchored on a Likert scale by 1 (strongly disagree) and 5 (strongly agree) in two (Novelty and Thrill Seeking) sub-dimension. Example items are "I am always trying to find new and exciting ways down a run" for Novelty Seeking sub-dimension; "I like to attempt jumps even if I'm not sure of the quality of the landing area" for Risk Seeking sub-dimension. EFA showed that the factor structure revealed two sub-dimensions, the factor load values of the items varied between .58 and .81 and covered $64 \%$ of the total variance. The CFA results showed that the model reached perfect and adequate fit indexes (x $2 / \mathrm{sd} 5$, CFI .95, GFI .95, AGFI .91, RMSEA .07) after with the necessary modification procedures and the factor load values of the items varied between .55 and .86 . Test-Retest correlation was $0.98(\mathrm{p}<.01)$ and Cronbach Alpha values were found to be 0.77 and 0.86 for two sub-scales respectively.

\subsubsection{Dispositional Flow Scale-2—Short Form (DFS2-SF)}

Dispositional Flow Scale-2 (DFS-2) was developed by Jackson and Eklund (2004) and Turkish adaptation was made by Aşçı et al. (2007). DFS-2, which is also states as Flow State, evaluates the optimal experience emotions which are experienced specifically in a physical activity; in other words, it reflects the optimal performance emotions experienced by the individual during the activity he/she takes part in the scale consists of 36 questions and nine subscales. Considering measuring process and the number of questions, the new version named Dispositional Flow Scale-2-Short Form (DFS2-SF) reedited by Çağlar et al. (2015) was used in the study. The scale has nine items and is in 5-point Likert type. The choices in the scale ranges between "1: never" and "5: always". Example items are "I was not worried about what others may have been thinking of me" and "I had a good idea while I was performing about how well I was doing". The factor analysis results of our study values for the scale explains $34.16 \%$ of the total variance, and it is seen that Cronbach Alpha value is .74. In order to use the short form of the scale, required permissions were obtained from the researchers.

\subsection{Data Collection Process}

Before the beginning of data collection process, conformity approval no. 27697707-302.14.01 was obtained from the Ethics Committee of Manisa Celal Bayar University Social Sciences Institute. The surveys were applied to ski and snowboard participants in various ski resorts both face to face and online on certain digital platforms.

\subsection{Statistics and Data Analysis}

IBM SPSS-20 package program was used for the analysis. Before the statistical analysis phase, skewness, 
kurtosis and normality (Kolmogorov-Smirnov test) values of the data were determined, and deviation from normal distribution was found insignificant $(p>.05)$ (Büyüköztürk, 2011). Before the structural equation analysis, Pearson Product Moment correlation analysis was carried out in order to determine the correlation level between variables. As Structural Equation Model (SEM) provides with a stronger substructure in explaining correlation levels, SEM was utilized. Forasmuch as SEM includes measurement and other residual errors into measurement when considering the variables in regression analysis. Also it is decided to use SEM in the study since it is a multi-variable method including many methods such as variance, covariance, multiple regression, factor analysis, and it is a secondary generation model in which models with high estimation and complex structures are systematically taken into account (Meydan \& Şeşen, 2015; Anderson \& Gerbing, 1988). The resulting significance of SEM was evaluated by the "Sobel Test" method. In this regard, the prerequisites must be fulfilled in order to use this method of analysis created Baron and Kenny (1986, p. 1176). If these conditions are not provided, it is not possible to mention the mediation influence.

\section{Results}

Demographic data (sex, age classes) as well as the preferred winter sport (skiing and snowboarding), domain preference, self-reported skiing ability (beginners, intermediates, advanced, experts) according to Sulheim et al. (2007) and Kopp et al. (2016) self-reported ski-track preference (What difficulty ski track do you usually prefer?) were questioned. Sociodemographic and skiing-related characteristics of the sample was presented in Table 1.

Table 1. Sociodemographic and skiing-related characteristics of the sample group

\begin{tabular}{lll}
\hline & F & $\%$ \\
\hline Sex & & \\
Female & 126 & 24. Tem \\
Male & 384 & 75.3 \\
Domain & & \\
Ski & 373 & 73,1 \\
Snowboard & 137 & 26,9 \\
Ability & & \\
Beginner & 166 & 32.6 \\
Intermediate & 192 & 37,6 \\
Advanced & 131 & 25,7 \\
Expert & 21 & 4,1 \\
Ski Track Preference & & \\
Green & 64 & 12,5 \\
Blue & 199 & 39 \\
Red & 187 & 36,7 \\
Black & 60 & 11,8 \\
\hline
\end{tabular}

In this study, ski resort preferences of ski and snowboard participants, causality relationships between contextual sensation seeking and flow state were tested with structural equality model (SEM). Accordingly, the model was taken as independent variable (ski resort preference), dependent variable (flow state) and mediator variable (contextual sensation seeking).

The results of the correlation analysis between the variables before SEM were given in Table 2.

Table 2. The results of the correlation analysis between the variables

\begin{tabular}{lllll}
\hline Variables & & 1 & 2 & 3 \\
Contextual Sensation Seeking (CSS) & $\mathrm{r}$ & 1 & $.196^{* *}$ & $.549^{* *}$ \\
Ski Resort Preference (SRP) & $\mathrm{r}$ & & & $.249^{* *}$ \\
Flow State (FS) & $\mathrm{r}$ & & 1 \\
\hline
\end{tabular}

Note. $\mathrm{p}<0.01 * *$.

Accordingly, a statistically significant relationship was found between ski resort preference and flow state ( $\mathrm{r}$ $=.249, \mathrm{p}<0.01)$, ski resort preference and contextual sensation seeking $(\mathrm{r}=.196, \mathrm{p}<0.01)$, contextual sensation seeking and flow state $(\mathrm{r}=.549, \mathrm{p}<0.01)$. 


\section{Model 1}

The results of SEM analysis for Model 1 were presented in Table 3.

Table 3. Regression coefficient for Model 1

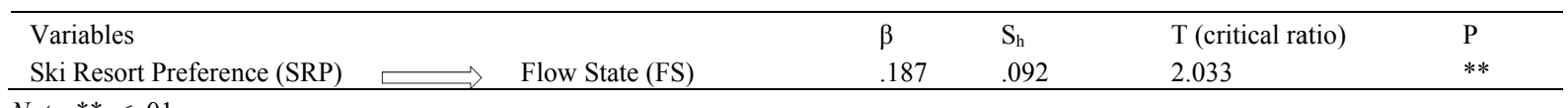

Note. $* * \mathrm{p}<.01$

According to the findings, there was a causal relationship between "Nature and Environment" sub-dimension of SRP and FS of skiers and snowboarders $(\beta=.187, \mathrm{p}<.01)$. The path diagram for Model-1 was presented in Figure 2.

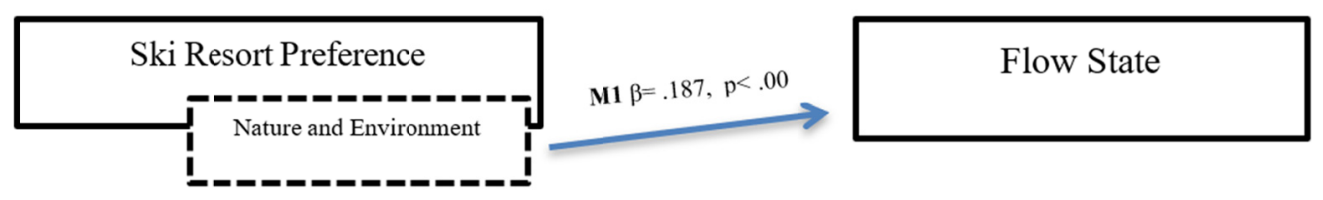

Figure 2. The path diagram for Model-1

When the fit indexes of the Model 1 were examined, all values indicated fairly well/good fit (x2/sd 2.78, CFI 0.92, GFI 0.95, AGFI 0.92, NFI 0.96, TLI 0.91 and RMSEA 0.05). The statistical significance of the established Model 1 was shown that the model was validated (Schermelleh et al., 2003, pp. 23-74).

\section{Model 2}

The results of SEM analysis for Model 2 were presented in Table 4.

Table 4. Regression coefficient for Model 2

\begin{tabular}{|c|c|c|c|c|c|c|}
\hline Variables & & & $\beta$ & $\mathrm{S}_{\mathrm{h}}$ & $\mathrm{T}$ (critical ratio) & $\mathrm{P}$ \\
\hline SRP (Alternative Services) & $\square$ & CSS (Novelty) & .932 & .280 & 3.329 & $* *$ \\
\hline SRP (Supporting Services) & $\square$ & CSS (Novelty) & -6.095 & 1.466 & -4.157 & $* *$ \\
\hline SRP (Accommodation \& Ski lift ) & $\longrightarrow$ & CSS (Novelty) & 4.806 & 1.194 & 4.025 & $* *$ \\
\hline SRP (Nature and Environment ) & $\square$ & CSS (Novelty) & -.732 & .363 & -2.019 & $* *$ \\
\hline SRP (Nature and Environment ) & $\square$ & CSS (Risk) & -1.486 & .594 & -2.504 & $*$ \\
\hline SRP (Supporting Services) & $\square$ & CSS (Risk) & -9.028 & 2.405 & -3.754 & $* *$ \\
\hline SRP (Accommodation \& Ski lift) & $\square$ & CSS (Risk) & 6.8 & 1.936 & 3.513 & ** \\
\hline
\end{tabular}

Note. ${ }^{*} \mathrm{p}<.05, * * \mathrm{p}<.01$.

According to the findings on Table 4 , there was a causal relationship between Alternative Activities $(\beta=.932$, $p$ $<.01)$, Supporting Services $(\beta=-6.095, \mathrm{p}<.01)$, Accommodation \& Ski Lift $(\beta=4.806, p<.01)$ and Nature and Environment $(\beta=-.732, p<.01)$ sub-dimension of Ski Resort Preference and "Novelty Seeking" sub-dimension of Contextual Sensation Seeking. It was also determined that Nature and Environment $(\beta=-1.486 p<.05)$, Supporting Services $(\beta=-9.028, \mathrm{p}<.01)$ and Accommodation \& Ski Lift $(\beta=6.8, \mathrm{p}<.01)$ sub-dimension of Ski Resort Preference and Risk-Seeking sub-dimension of Contextual Sensation Seeking. The path diagram for Model-2 was presented in Figure 3. 


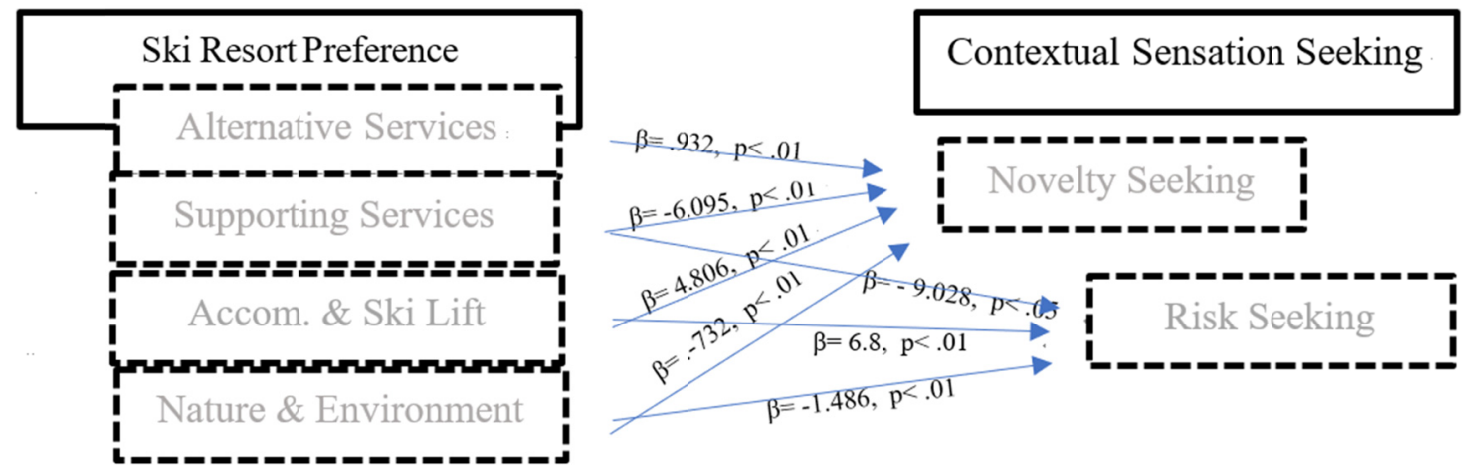

Figure 3. The path diagram for Model-2

When the fit indexes of the Model 2 were examined, all values indicated fairly well/good fit $\left(\mathrm{x}^{2} / \mathrm{sd} 3.03\right.$, CFI 0.91, GFI 0.88, AGFI 0.86, NFI 0.88, TLI 0.90, RMSEA 0.05). The statistical significance of the Model 2 was shown that the model was validated (Schermelleh et al., 2003, pp. 23-74).

Model 3

The results of SEM analysis for Model 3 were presented in Table 5.

Table 5. Regression coefficient for Model 3

\begin{tabular}{|c|c|c|c|c|c|c|}
\hline $\begin{array}{l}\text { Variables } \\
\text { CSS (Novelty Seeking) }\end{array}$ & $\Longrightarrow$ & Flow State & $\begin{array}{l}\beta \\
.581\end{array}$ & $\begin{array}{l}\mathrm{S}_{\mathrm{h}} \\
.050\end{array}$ & $\begin{array}{l}\mathrm{T} \text { (critical ratio) } \\
11.680\end{array}$ & $\begin{array}{l}\mathrm{P} \\
* *\end{array}$ \\
\hline
\end{tabular}

According to the findings on Table 5, there was a causal relationship between "Novelty Seeking" sub-dimension of Contextual Sensation Seeking and Flow State of skiers and snowboarders $(\beta=.581, \mathrm{p}<.01)$. The path diagram for Model-3 was presented in Figure 4.

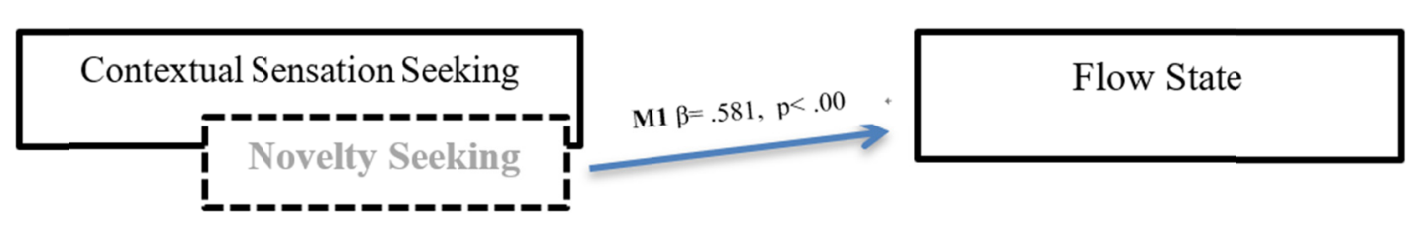

Figure 4. The path diagram for Model-3

When the fit indexes of the Model 3 were examined, all values indicated fairly well/good fit $\left(\mathrm{x}^{2} / \mathrm{sd} 3.60\right.$, CFI 0.92 , GFI 0.91, AGFI 0.89, NFI 0.88, TLI $0.91 \&$ RMSEA 0.06). The statistical significance of the Model 3 was shown that the model was validated (Schermelleh et al., 2003, pp. 23-74).

\section{Model 4}

The results of SEM analysis for Model 4 were presented in Table 6. 
Table 6. Regression coefficient for Model 4

\begin{tabular}{|c|c|c|c|c|c|}
\hline Variables a & Variables b & $\beta$ & $\mathbf{S}_{\mathrm{h}}$ & $T$ (critical ratio) & $\mathbf{P}$ \\
\hline SRP (Alternative Services) & $\Longrightarrow$ CSS (Novelty) & 2,439 & 502 & 4,861 & $* *$ \\
\hline SRP (Supporting Services) & $\Longrightarrow$ CSS (Novelty) & $-2,928$ & ,648 & $-4,516$ & $* *$ \\
\hline SRP (Accommodation \& Ski lift) & $\Longrightarrow$ CSS (Novelty) & 1,320 & ,438 & 3,018 & $* *$ \\
\hline SRP (Nature and Environment) & $\Longrightarrow$ CSS (Novelty) & $-1,425$ &, 412 & $-3,459$ & ** \\
\hline CSS (Novelty) & $\Longrightarrow \mathrm{FS}$ & .722 & .114 & 6.31 & $* *$ \\
\hline SRP (Alternative Services) & $\Longrightarrow \mathrm{FS}$ & $-6,312$ & 9,562 &,- 660 & ,509 \\
\hline SRP (Supporting Services) & $\Longrightarrow \mathrm{FS}$ & 7,067 & 10,389 & 680 & ,496 \\
\hline SRP (Accommodation \& Ski lift) & $\Longrightarrow \mathrm{FS}$ & $-2,689$ & 4,123 &,- 652 &, 514 \\
\hline SRP (Nature and Environment) & $\Longrightarrow \mathrm{FS}$ & 4,167 & 6,474 & ,644 &, 520 \\
\hline SRP (Alternative Services) & $\Longrightarrow$ CSS (Risk) & 4,963 & 1,446 & 3,433 & $* *$ \\
\hline SRP (Supporting Services) & $\Longrightarrow$ CSS (Risk) & $-5,462$ & 1,604 & $-3,406$ & $* *$ \\
\hline SRP (Accommodation \& Ski Lift) & $\Longrightarrow$ CSS (Risk) & 2,124 & ,906 & 2,345 & $* *$ \\
\hline SRP (Nature and Environment) & $\Longrightarrow$ CSS (Risk) & $-3,285$ & 1,130 & $-2,906$ & $* *$ \\
\hline CSS (Risk) & $\Longrightarrow \mathrm{FS}$ & 1,037 & 1,632 &, 635 &, 525 \\
\hline
\end{tabular}

The regression coefficient, standard error, critical ratio and p value for the Model 4 was shown on Table 6 . According to the findings, there were causal relationship between all sub-dimensions of SRP and all sub-dimensions of CSS. When the CSS was included as a mediator variable to the model, the causal effect between SRP and FS in all sub-dimensions were disappeared $(\mathrm{p}>.01)$ and a causal relationship between CSS (novelty seeking) and FS in Model 3 was significantly increase in model $4(\beta=.722, p<.01)$. The road diagram for Model-4 was presented in Figure 5.

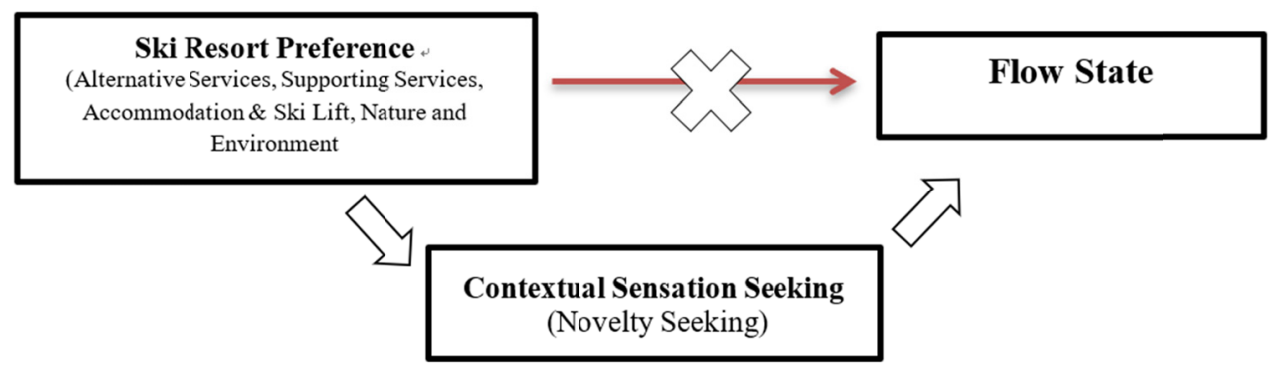

Figure 5. The path diagram for Model-4

When the fit indexes of the Model 4 were examined, all values indicated fairly well / good fit $\left(\mathrm{x}^{2} / \mathrm{sd} 2.58, \mathrm{CFI}\right.$ 0.91, GFI 0.87, AGFI 0.85, NFI 0.90, TLI 0.90 \& RMSEA 0.05). The statistical significance of the established Model 4 has shown that the model is validated (Schermelleh et al., 2003, pp. 23-74).

These findings have pointed out that the influence of Ski Resort Preference and Flow State could be the full mediation influence of Contextual Sensation Seeking (Novelty Seeking). The existence of the resulting significance was decided by the "Sobel, Aroian and Goodman Tests" method as seen Table 7. 
Table 7. Sobel, Aroian and Goodman tests results

\begin{tabular}{|c|c|c|c|c|c|c|c|}
\hline & & $\boldsymbol{\beta}$ & Sh & Test & Z-Coefficient & Sd & $\mathbf{P}$ \\
\hline \multirow[t]{2}{*}{ SRP (Alternatife Services) } & CSS (Novelty) & 2.439 & 0.502 & Sobel & 3.854 & 0.456 & 0.00 \\
\hline & & & & Aroian & 3.825 & 0.46 & 0.00 \\
\hline \multirow[t]{2}{*}{ CSS (Novelty) } & FS & 0.722 & 0.114 & & & & \\
\hline & & & & Goodman & 3.825 & 0.453 & 0.00 \\
\hline \multirow[t]{2}{*}{ SRP (Supporting Services) } & CSS (Novelty) & -2.93 & 0.648 & Sobel & -3.678 & 0.574 & 0.00 \\
\hline & & & & Aroian & -3.648 & 0.579 & 0.00 \\
\hline \multirow[t]{2}{*}{ CSS (Novelty) } & FS & 0.722 & 0.114 & & & & \\
\hline & & & & Goodman & -3.709 & 0.569 & 0.00 \\
\hline \multirow[t]{2}{*}{ SRP(Accommodation \& Ski lift) } & CSS (Novelty) & 1.32 & 0.438 & Sobel & 2.721 & 0.35 & 0.00 \\
\hline & & & & Aroian & 2.694 & 0.353 & 0.00 \\
\hline \multirow[t]{2}{*}{ CSS (Novelty) } & FS & 0.722 & 0.114 & & & & \\
\hline & & & & Goodman & 2.749 & 0.346 & 0.00 \\
\hline \multirow[t]{2}{*}{ SRP (Nature \& Environment) } & CSS (Novelty) & -1.43 & 0.412 & Sobel & -3.035 & 0.338 & 0.00 \\
\hline & & & & Aroian & -3.006 & 0.342 & 0.00 \\
\hline \multirow[t]{2}{*}{ CSS (Novelty) } & FS & 0.722 & 0.114 & & & & \\
\hline & & & & Goodman & -3.065 & 0.335 & 0.00 \\
\hline \multirow[t]{2}{*}{ SRP (Alternative Services) } & CSS (Risk) & 4.963 & 1.446 & Sobel & 0.624 & 8.237 & 0.532 \\
\hline & & & & Aroian & 0.6 & 8.568 & 0.548 \\
\hline \multirow[t]{2}{*}{ CSS (Risk) } & FS & 1.037 & 1.632 & & & & \\
\hline & & & & Goodman & 0.652 & 7.891 & 0.514 \\
\hline \multirow[t]{2}{*}{ SRP (Supporting Services) } & CSS (Risk) & -5.46 & 1.604 & Sobel & -0.624 & 9.067 & 0.532 \\
\hline & & & & Aroian & -0.6 & 9.438 & 0.548 \\
\hline \multirow[t]{2}{*}{ CSS (Risk) } & FS & 1.037 & 1.632 & & & & \\
\hline & & & & Goodman & -0.652 & 8.681 & 0.514 \\
\hline \multirow[t]{2}{*}{ SRP(Accommodation \& Ski lift) } & CSS (Risk) & 2.124 & 0.906 & Sobel & 0.613 & 3.591 & 0.539 \\
\hline & & & & Aroian & 0.567 & 3.883 & 0.57 \\
\hline \multirow[t]{2}{*}{ CSS (Risk) } & FS & 1.037 & 1.632 & & & & \\
\hline & & & & Goodman & 0.672 & 3.272 & 0.5 \\
\hline \multirow[t]{2}{*}{ SRP (Nature \& Environment) } & CSS (Risk) & -3.29 & 1.13 & Sobel & -0.62 & 5.487 & 0.534 \\
\hline & & & & Aroian & -0.588 & 5.789 & 0.556 \\
\hline \multirow[t]{2}{*}{ CSS (Risk) } & FS & 1.037 & 1.632 & & & & \\
\hline & & & & Goodman & -0.659 & 5.168 & 0.509 \\
\hline
\end{tabular}

Note. $\mathbf{a}=$ Ski Resort Preference (SRP)/Contextual Sensation Seeking (CSS); $\mathrm{Sa}=$ Standard error (a)

$\mathbf{B}=$ Contextual Sensation Seeking (CSS)/Flow State (FS); $\mathrm{Sb}=$ Standard error (b).

It was concluded that the effect of Contextual Sensation Seeking (Novelty Seeking) on Ski Resort Preference (all sub-dimensions) and its influence on Flow State has a full mediating effect due to the fact that according to Sobel, Aroian and Goodman tests results $(\mathrm{p}<.01)$ for Model 3. The holistic path diagram obtained by testing the hypotheses related to each model with SEM was presented in Figure 6. 


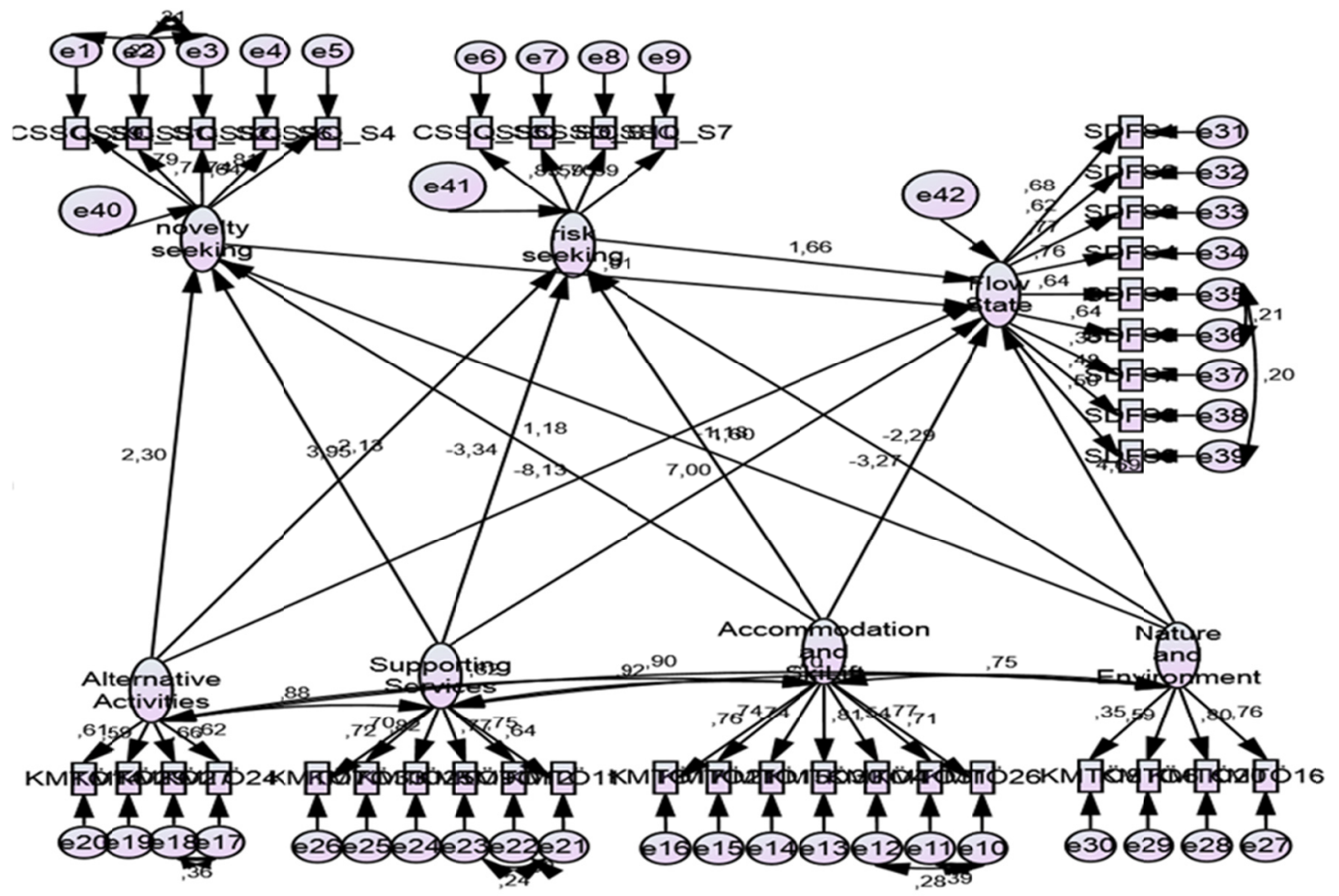

Figure 6. Path diagram related to SEM

\section{Discussion}

In this study, the relationship between Flow State and Contextual Sensation Seeking in the ski resort preference of individuals who engage in snowboarding and skiing was examined. As a result of the correlation analysis regarding the study, a statistically significant relationship was found between Ski Resort Preference and Flow State $(r=.249, \mathrm{p}<0.01)$, Ski Resort Preference and sensation seeking $(r=.196, p<0.01)$, and sensation seeking and Flow State $(\mathrm{r}=.549, \mathrm{p}<0.01)$.

In the study, a theoretical model was developed among Ski Resort Preference, Sensation Seeking and Flow State by referring to the literature. In the Structural Equation Model established for the study, "Ski Resort Preference" was designated as the independent variable, "Flow State" was designated as the dependent variable and "sensation seeking" was designated as the mediating variable. Accordingly, the established models were tested by assuming that the independent variable (Ski Resort Preference) affected the dependent variable (Flow State), the independent variable (Ski Resort Preference) affected the mediating variable (Sensation Seeking), and the mediating variable (Sensation Seeking) affected the dependent variable (Flow State).

The effect relationships between the ski resort preferences, sensation seeking conditions, and flow state conditions of the participants of snowboarding and skiing were tested with the structural equation model. Accordingly, the model was designated with an independent variable (Ski Resort Preference), a dependent variable (Flow State), and a mediating variable (Sensation Seeking).

H(1) In the model developed between Ski Resort Preference and Flow State, it was found that the "Nature and Environment" sub-dimension of Ski Resort Preference affected Flow State $(\beta=.187, p<.01)$ and that the $\mathrm{p}$-value was statistically significant $(\mathrm{p}<.01)$. The fact that the Nature and Environment sub-dimension affects Flow State can be explained by the sense of satisfaction people will experience due to the scenery of unbroken (deep powder) tracks and forested lands where they chose to perform the activities at. Because various studies show that while some participants view adventure seeking as an opportunity to study and enjoy nature, another aim is physical and spiritual restoration (Driver et al., 1996; Lekies, Yost, \& Rode, 2015). In the "enjoy nature" sub-dimension included in the Recreation Experience Preference Scales developed by Driver et al. (1996), the directing effect of nature in the recreation experience is emphasized. On the other hand, Buckley (2012), who compiled close to fifty studies on the motivation to participate in the adventure recreation, also stated that natural environment variables have a directing effect for the participant. The studies also show that early adventure 
experience affects environmental sensitivity in later years (Chawla \& Derr, 2012), provides a more positive perception towards the natural environment (Bixler, Floyd, \& Hammitt, 2002) and increases orientation towards nature-related professions (James et al., 2010). Therefore, the beauty and variety of natural areas (forested lands, panoramic image depth etc.) can increase the value of facilities in the eyes of the participants receiving services from ski resorts and become an important factor that can affect customer loyalty and preference towards the resort.

H(2) Table 3 shows the regression coefficient, standard error, critical ratio and p-value for the second developed model. According to the findings, it was determined that there was a causal relationship between the Alternative Activities $(\beta=.932, \mathrm{p}<.01)$, Support Services $(\beta=-6.095, \mathrm{p}<.01)$, Accommodation \& Transportation Services $(\beta=4.806, p<.01)$, and Nature \& Environment $(\beta=-.732, p<.01)$ sub-dimensions of "Ski Resort Preference" and the Novelty Seeking sub-dimension of "Sensation Seeking". It was also found that there was a causal relationship between the Nature \& Environment $(\beta=-1.486, p<.05)$, Support Services $(\beta=-9.028, p<.01)$ and Accommodation \& Transportation Services $(\beta=6.800, \mathrm{p}<.01)$ sub-dimensions of "Ski Resort Preference" and the Risk Seeking sub-dimension of "Sensation Seeking". It can be said that the participants who seek novelty are not interested in the service-oriented features of ski resorts, and that what is important for them are new tracks, deep powder tracks, natural environment and snow park, and entertainment opportunities. Such that, a novelty seeking participant may not complain if they are given the opportunity to stay in a bad hotel, but they may do so if they are not presented with a track environment that satisfies them. In his study investigating the effects of perceived value dimensions on perceived risk, Erdoğan (2016) states that service buyers perceiving that they may encounter certain risks after the purchase prevents them from deeming these facilities, their personnel, and their pricing valuable. In this sense, in order to increase the value level perceived by the participants in the resorts, it is necessary to determine how the quality of the presented service or product is perceived by the participant and not by themselves. There are studies supporting the model of the study, stating that there is a relationship between perceived value and perceived risk (Agarwal \& Teas, 2004; Chen et al., 2005). Fuchs and Arie (2006) determined that there was a significant relationship between perceived risk dimensions and service quality in the tourism sector. According to the study conducted; there is a significant relationship between service quality and general risk, human-related risk, socio-psychological risk, risks related to food safety and weather, financial risk, natural risks and accident risk. In their study, Konu et al. (2011) stated that the adequacy of services and the diversity and difficulty of tracks can be considered as the most important variables for the preference of ski resorts.

H(3) In the model developed between Sensation Seeking and Flow State, it was determined that the "Novelty Seeking" sub-dimension of Sensation Seeking had an effect on Flow State $(\beta=.581, \mathrm{p}<.01)$. There is no evidence of the existence of a direct relationship between Sensation Seeking and Flow State in the literature. However, in their study, Gözmen and Aşçı (2016) stated that personality traits were predictors of flow state. Goma-i Freixanet et al. (2012) associated participation in high-risk adventure sports with the personality trait of sensation seeking, as in high-risk social activities. From this viewpoint, the personality trait of sensation seeking can have features that are predictive of flow state such as openness for improvement and self-control in athletes (Gözmen \& Aşç1, 2016). In his study, Eachus (2004) determined that participants with high scores from the sensation and adventure seeking sub-dimension tend to prefer adventurous vacations. Hoyle et al. (2002) state that sensation seeking individuals perceived risk possibilities in activities less. The state of being open to new experiences may be influential in sensation seeking individuals experiencing flow experience. An association can be made with being open to experiences, flexibility, curiosity, artistic sensitivity, a rich imagination, and non-traditional attitudes. It is stated that individuals who are open to experiences are eager to achieve new experiences and that they don't demonstrate a conservative approach (Çivitci \& Arıcıoğlu, 2012). The participant can take the risks of the event for the sake of experiencing it. This situation matches up with the effect of sensation seeking on flow experience. The participant can take risks for the sake of experiencing flow experience in the activities they participate in with the aim of sensation seeking. However, taking risks does not mean acting impulsively. Sensation seeking participants attempt to minimize risks by taking precautions (Roberti, 2004). In his study, Ayazlar (2015) states that the sensation seeking mood of paragliding participants has a positive effect on them experiencing flow experience. Recent studies conducted on athletes prove the existence of the physiological excitement in flow experience. These results support the model presented in our study. Participants demonstrate a balanced personality by establishing optimum experience with the effort they show and the emotional intensity they perceive from their related skills. It is stated in the studies conducted that the balance of effort and skill alone would not be enough to estimate the formation of emotional intensity. In order for emotional intensity (flow state/flow theory) to emerge, effort and skill must exceed a certain threshold. Even if the levels of both effort and skill are low, the result includes insensibility for emotional intensity. The 
motivation towards various leisure activities that require high levels of skill and effort, some of which even include danger and risk, is expressed with the concept of emotional intensity (Hills \& Argyle, 2001). The concept of emotional intensity is the full devotion developed by the individual towards the activity they engage in, the desire to complete it within the allocated time period, and the mental expression of the operation of the emotion they developed by directing all of their energy towards the activity (Csikzentmihalyi, 1990).

H(4) A model was developed on the mediating role of Sensation Seeking in the effect of the Ski Resort Preferences of the participants of skiing and snowboarding to Flow State. According to the findings, there is an effect between Ski Resort Preference and Flow State. With the inclusion of the Sensation Seeking variable into the model as the mediating variable, it was found that the effect between Ski Resort Preference and Flow State disappeared for all sub-dimensions $(\mathrm{p}>.01)$. When Sensation Seeking is taken as the mediating variable, it was found that the effect of the "Novelty Seeking" sub-dimension of Sensation Seeking on Flow State $(\beta=.722, p$ $<.01)$ increased. In the literature, various studies were conducted in different fields on sensation seeking, ski resort preference and flow state individually or with dichotomous variables. Sensation seeking, desire to take risks, and the sense of pleasure reflect the characteristic features of extreme sports. That is because participants of extreme sports (e.i. skiing and snowboarding) take part in such sports while taking risks for the sake of the high levels of pleasure and excitement that arise from the activities. The fact that participants take part in these activities for the sake of excitement and pleasure even when the risk of death is present can be stated as the most important feature that distinguishes extreme sports from other branches of sports (Şimşek, 2010). Increasing difficulty in adventure activity increases the level of satisfaction of the participants (Tsaur, Lin, \& Cheng, 2015). Nevertheless, in our study, it can be said that ski and snowboard participants were prefered ski resort according to their feelings of seeking for novelty. This is a result of the fact that the participants prefer skiing centers which they have not experienced before, and create a higher flow situation for them, rather than the dangerous ski runs and skiing style.

This suggests the peak performance approach in Flow State Theory. Csikszentmihalyi (1990) called the state of flow as the most appropriate psychological state resulting from the balance between perceived difficulties and skills in an activity. The peak performance state is that the individual reaches the optimal sportive performance as well as the optimal experience in the activity. Considering our $\mathrm{H} 4$ findings, individuals may be more likely to achieve peak performance when they find ski slope services with difficulty and variation to match their quest for sensation seeking. In addition, the perception of stress/challenge in recreation is associated with regeneration and excitement and these emotions can positively affect the level of satisfaction (Duman \& Mattila, 2005). Therefore, the preferences of the participants regarding the ski centers they serve may affect their flow situations in line with their individual quest for excitement. Because, it was found that there were significant correlations between risk taking and many features such as Reward Sensitivity, Punishment Sensitivity and Sensation Seeking in downhill speed activities such as skiing and snowboarding (Maher et al., 2015).

The perceived value and satisfaction of the participant are concepts that have been attracting interest and widely studied in the field of marketing in recent years (Huber et al., 2001; Eggert \& Ulaga, 2002). The reason why the number of studies on these concepts increased is the effects developing on the thoughts and decisions of participants after purchasing services (Lin et al., 2005; Eggert \& Ulaga, 2002; McDougall \& Levesque, 2000). From this viewpoint, if ski resorts providing services are able to meet the requirements of participants by giving more value to them, the satisfaction level regarding the purchased service may increase and customer loyalty may be established in line with the experienced flow state. That is because satisfaction occurs if the performance of the service presented is in line with or exceeds the expectations of the participant (Parasuraman et al.,1988; Eggert \& Ulaga, 2002). The reversal of this situation leads to the emergence of dissatisfaction. Satisfied participants reveal their intentions behaviorally. In this case, the participant purchasing the service will be enabled to revisit the resorts and recommend them to their friends. The variable of critical importance in this situation is sensation seeking. Sensation seeking is characterized by events that desire to participate in risky and adventurous activities such as skiing, mountaineering and parachuting that include the sense of speed or challenging gravity (Koop et al. 2016; Hittner \& Swickert, 2006). Individuals with high urges of sensation seeking have higher expectations of difficulty and risk from the activities they have not experienced before. Individuals who are likely to realize this expectation are more likely to participate in the activities (Zuckerman \& Kuhlman, 2000). Therefore, the presence of more challenging tracks (steep, fast and inclined tracks and/or areas with off-track features) in the preferred ski resort and the installation of well-planned lifts for such tracks may elevate the flow state of individuals with high sensation seeking levels. Therefore, it may increase customer loyalty towards the resort.

There are many variables that affect participation in outdoor and adventure activities such as skiing and 
snowboarding. Many influences such as motivation, psycho-social characteristics of individuals, variability of environmental conditions, and activity experiences can change the preferences of the participants. Therefore, the relationships between these different variables can be examined in future researches. Especially in winter, one of the important recreation areas is the ski resorts. There are participants from many different purposes. So, increasing the sample size is recommended for future studies in the investigation of ski resort preferences. Increasing the sample size and type of activities for future research is important to extrapolation clearer. On the other hand, examining the relationship between sensation seeking, risk taking and flow state in different outdoor adventure areas between individuals with different experiences and individual characteristics may shed light on future studies. During the data collection period of the research, we saw the significant benefits of CSSQ-S, which puts the search for excitement about skiing and snowboarding with special expressions. In particular, the propositions that the participants mark with field-specific phrases without the need for explanation can increase the internal consistency of the research results. In the quest for sensation seeking (SSS_V, ImSS, AISS, etc.) for the general participants, only certain reactions are presented for the adventure participant. Therefore, the development of SS search and risk-taking instruments that will be developed specifically for other high-risk and dangerous outdoor adventure activities can be carried out with similar research method approaches. Considering this situation, it will be useful to examine the effect of different variables on risk-taking behavior of outdoor adventurer in future studies.

\section{Acknowledgments}

The data of this study includes a part of the master thesis (taken by the ethics committee permission) produced in the Recreation Department of Social Sciences Institute at Manisa Celal Bayar University in Turkey. Any grants or other financial support was not received for our study. I assert that written informed consent was taken from participants for reporting the results. The manuscript is original work of all authors and each made a significant contribution on this study. None of the writers is the person's routinely involved in the review and acceptance of manuscripts peer reviewers and editors associate editors, and consulting editors of the journal. I confirm that this manuscript has not been published elsewhere nor is it currently under consideration for publication in any other journal. I affirmed that all authors have read and approved the final version of the manuscript.

\section{Referances}

Agarwal, S., \& Teas, R. K. (2004). Cross-national Applicability of a Perceived Risk-Value Model. Journal of Product \& Brand Management, 13(4), 242-256. https://doi.org/10.1108/10610420410546952

Alexandris, K., Kouthouris, C., \& Meligdis, A. (2006). Increasing Customers' Loyalty on a Skiing Resort: The Contribution of Place Attachment and Service Quality. International Journal of Contemporary Hospitality Management, 18(5), 414-425. https://doi.org/10.1108/09596110610673547

Anderson, J. C., \& Gerbing, D. W. (1988). Structural Equation Modeling in Practice: A Review and Recommended Two-Step Approach. Psychological Bulletin, 103(3), 411. https://doi.org/10.1037/0033-2909.103.3.411

Aslan, M., \& Koçak, M. S. (2011). Determination of The Service Quality Among Sport and Fitness Centers of the Selected Universities. International Journal of Human Sciences, 8(2), 817-833.

Ayazlar, A. R. (2015). Akış Deneyiminin Yamaç Paraşütü Deneyim Doyumu ve Yaşam Doyumuna Etkileri (pp. 107-108). Doktora Tezi, Adnan Menderes Üniversitesi Sosyal Bilimler Enstitüsü Turizm İşletmeciliği Anabilim Dalı.

Balcı, A. (2009). Sosyal Bilimlerde Araştırma Yöntem Teknik ve İlkeler (7. Baskı). Pegem Akademi, Ankara.

Baron, R. M., \& Kenny, D. A. (1986). The Moderator-Mediator Variable Distinction in Social Psychological Research: Conceptual, Strategic, and Statistical Considerations. Journal of Personality and Social Psychology, 51(6), 1173-1182. https://doi.org/10.1037/0022-3514.51.6.1173

Bixler, R. D., Floyd, M. F., \& Hammitt, W. E. (2002). Environmental socialization: Quantitative test of the childhood play hypothesis. Environment and Behavior, 34, 795-818. https://doi.org/10.1177/001391602237248

Brymer, E. (2010). Risk and Extreme Sports: A Phenomenological Perspective. Annals of Leisure Research, 13, 218-239. https://doi.org/10.1080/11745398.2010.9686845

Brymer, E., \& Oades, L. G. (2009). Extreme sports a positive transformation in courage and humility. Journal of Humanistic Psychology, 49(1), 114-126. https://doi.org/10.1177/0022167808326199

Burtscher, M., Bodner, T., Burtscher, J., Ruedl, G., Kopp, M., \& Broessner, G. (2013). Life-Style Characteristics 
and Cardiovascular Risk Factors in Regular Downhill Skiers: An Observational Study. BMC Public Health, 13, 788. https://doi.org/10.1186/1471-2458-13-788

Büyüköztürk, Ş. (2011). Sosyal Bilimler İçin Veri Analizi El Kitabı: İstatistik, Araştırma Deseni, Spss Uygulamalarl ve Yorum (pp. 85-90, 175-181). Pegem Yayinevi.

Çağlar, E., Sarı, İ., Aş̧̧ı, F. H., Jackson, S. \& Eklund, R. (2015). The Short Version of Flow Scales: Reliability and Validity Study. III. International Exercise and Sport Psychology Congress, 48, 23-25 October.

Castanier, C., Le Scanff, C., \& Woodman, T. (2010b). Who Takes Risks in High-Risk Sports? A Typological Personality Approach. Research Quarterly for Exercise and Sport, 81(4), 478-484. https://doi.org/10.1080/02701367.2010.10599709

Chen, T., Chang, P. L., \& Chang, H. S. (2005). Price, Brand Cues, and Banking Customer Value. The International Journal of Banking Marketing, 3, 273-291. https://doi.org/10.1108/02652320510591720

Cihangiroğlu, N., \& Şahin, B. (2012). Organizasyonlarda Önemli Bir Fenomen: Psikolojik Sözleşme. Uluslararası Yönetim İktisat ve Işsletme Dergisi, 6(11), 1-16.

Çivitci, N., \& Arıcıŏlu, A. (2012). Beş Faktör Kuramına Dayalı Kişilik Özellikleri, Mehmet Akif Ersoy Üniversitesi Ĕ̈itim Fakültesi Dergisi, 12(23), 78-96.

Cronin, J. J., \& Taylor, S. (1992). Measuring Service Quality: A Re-examination and Extension. Journal of Marketing, 56, 55-68. https://doi.org/10.1177/002224299205600304

Csikszentmihalyi, M. (1990). Flow: The Psychology of Optimal Experience (vol. 1, pp. 71-95). New York: Harper \& Row.

Csikszentmihalyi, M. (1992). A response to the Kimiecik \& Stein and Jackson papers. Journal of Applied Sport Psychology, 4(18), 1-18. https://doi.org/10.1080/10413209208406460

Csikszentmihalyi, M., \& Csikszentmihalyi, I. S. (1991). Adventure and The Flow Experience. In J. C. Miles \& S. Priest (Eds.), Adventure Education (pp. 149-155). State College, PA Venture.

Demirhan, G. (2003). Doğa Sporlarına İlişkin Riskin Algılanması. Spor Bilimleri Dergisi, 14(1), 1-13.

Demirhan, G., Aşçı H. F., Kangalgil, M., \& Saraçbaşı, O. (2014). Perception of Risk and Attractiveness of Extreme Sports among Turkish University Students. Hacettepe Journal of Sport Sciences, 25(1), 11-22.

Dinç, S. C. (2018). Doğa Sporları Etkinliklerine Illişkin Liderlik Ölçeğinin Gelişstirilmesi. Ankara: Spor Yayınevi.

Dinç, S. C., \& Demircan, M. (2019). The Contextual Sensation Seeking Questionnaire for Skiing and Snowboarding (CSSQ-S): The Study of Validity and Reliability in Turkish. Int. J. Of Sport Exercises and Training Science, 5(3) (on press).

Dolnicar, S., \& Leisch, F. (2003). Winter Tourist Segments in Austria: İdentifying Stable Vacation Styles Using Bagged Clustering Techniques. Journal of Travel Research, 41(3), 281-292. https://doi.org/10.1177/0047287502239037

Driver, B. L. Manfredo, M. J., \& Tarrant, M. (1996) Measuring leisure motivations: A Meta-Analysis of the Recreation Experience Preference Scales. Journal of Leisure Research, 28(3), 188-213. https://doi.org/10.1080/00222216.1996.11949770

Duman, T., \& Mattila, A. S. (2005). The role of affective factors on perceived cruise vacation value. Tourism Management, 26, 311-323. https://doi.org/10.1016/j.tourman.2003.11.014

Eachus, P. (2004). Using the Brief Sensation Seeking Scale (BSSS) to Predict Holiday Preferences. Personality and Individual Differences, 36, 141-153. https://doi.org/10.1016/S0191-8869(03)00074-6

Eggert, A., \& Ulaga, W. (2002). Customer Perceived Value: A Substitute For satisfaction in Business Markets? $\begin{array}{lllll}\text { Journal of Business \& Industrial Marketing, } & \text { 17(2/3), 107-118. }\end{array}$ https://doi.org/10.1108/08858620210419754

Ellis, M. J. (1973). Why People Play. Englewood Cliffs, Prentice-Hall, NJ.

Erdoğan, A. (2016). Algllanan Hizmet Kalitesi, Hizmet Değeri ve Memnuniyet Üzerinde Algllanan Risk Faktörünün Etkisi: Sağllklı Yaşam ve Spor Merkezleri Üzerine Bir Uygulama (pp. 105-108). Yüksek Lisans Tezi. Selçuk Üniversitesi Sağlık Bilimleri Enstitüsü.

Ewert, A., Place, G., \& Sibthorp, J. (2005). Early-life outdoor experiences and anindividual's environmental 
attitudes. Leisure Sciences, 27, 225-239. https://doi.org/10.1080/01490400590930853

Fuchs, G., \& Arie, R. (2006). Tourist Destination Risk Perception: The Case of Israel. Journal of Hospitality and Leisure Marketing, 2, 83-108. https://doi.org/10.1300/J150v14n02_06

Gencer, T., Demir, C., \& Aycan, A. (2008). Kayak Merkezlerindeki Spor Turistlerinin Hizmet Kalite Algılarını Etkileyen Değişkenler. Ege Akademik Bakış, 8(2),437-450. https://doi.org/10.21121/eab.2016121903

Gögercin, T. (2017). Beden Eğitimi Öğretmenlerinin İş Tatmini Ve Mesleki Tükenmişlik Düzeylerinin İncelenmesi (İstanbul Başakşsehir İlçesi Örneği). Master's Thesis, İstanbul Gelişim Üniversitesi Sağllk Bilimleri Enstitüsü.

Gözmen, A., \& Aşçı, F. H. (2016). Sporcularda Optimal Performans Duygu Durumunun Yordanmasında Beş Faktörlü Kişilik Özelliklerinin ve Mükemmeliyetçiliğin Rolü. Spor Bilimleri Dergisi, 27(1), 40-48. https://doi.org/10.17644/sbd.251312

Grönross, C. (1984). A Service Quality Model and 1t's Market Implications, European Journal of Marketing, 18(4), 36-44. https://doi.org/10.1108/EUM0000000004784

Harrison, H. T., \& Chalip, L. (2005). Marketing Sport Tourism: Creating Synergy between Sport and Destination. Sport in Society, 8(2), 302-320. https://doi.org/10.1080/17430430500102150

Hektner, J. M., \& Csikszentmihalyi, M. (1996). Annual Meeting of the American Educational Research Association: A Longitudinal Exploration of Flow and Intrinsic Motivation in Adolescents. University of Chicago.

Hills, P., \& Argyle, M. (2001). Happiness, Introversion Extra Version and Happy Introverts. Personality and Individual Differences, 30(4), 595-608. https://doi.org/10.1016/S0191-8869(00)00058-1

Hoyle, R. H., Stephenson, M. T., Palmgreen, P., Lorch, E. P., \& Donohew, R. L. (2002). Reliability and Validity of a Brief Measure of Sensation Seeking, Personality and Individual Differences, 32, 401-414. https://doi.org/10.1016/S0191-8869(01)00032-0

Huber, F., Herman, A., \& Morgan, R. E. (2001). Gaining Competitive Advantage Through Customer Value Oriented Management. Journal of Consumer Marketing, 18, 41-53. https://doi.org/10.1108/07363760110365796

Jackson, S. A. (1992). Athletes in flow: A qualitative investigation of flow states in elite figure skaters. Journal of Applied Sport Psychology, 4, 161-180. https://doi.org/10.1080/10413209208406459

Jackson, S. A., \& Eklund, R. C. (2004). The Flow Scales Manual. Morgantown. WV: Fitness Information Technology, Inc.

Jackson, S. A., \& Marsh, H. W. (1996). Development and Validation of a Scale to Measure Optimal Experience: The Flow State Scale. Journal of Sport \& Exercise Psychology, 18, 17-35. https://doi.org/10.1123/jsep.18.1.17

Jackson, S. A., Thomas, P. R., Marsh, H. W., \& Smethurst, C. S. (2001). Relationships Between Flow, Self-Concept, Psychological Skills and Performance, Journal of Applied Sport Psychology, 13, 129-153. https://doi.org/10.1080/104132001753149865

Jenkins, J. M., \& Pigram, J. J. (2003). Encyclopedia of Leisure and Outdoor Recreation. London and New York: Routledge, Taylor \& Francis Group.

Judge, T. A., \& Ilies, R. (2002). Relationship of Personality to Performance Motivation: A Meta-Analytic Review. The Journal of Applied Psychology, 87(4), 797-807. https://doi.org/10.1037/0021-9010.87.4.797

Komarraju, M., Karau S. J., \& Schmeck, R. R. (2009). Role of The Big Five Personality Traits in Predicting College Students' Academic Motivation and Achievement. Learning and Individual Differences, 19(1), 4752. https://doi.org/10.1016/j.lindif.2008.07.001

Konu, H., Laukkanen, T., \& Komppula, R. (2011). Using Ski Destination Choice Criteria to Segment Finnish Ski Resort Customers. Tourism Management, 32(5), 1096-1105. https://doi.org/10.1016/j.tourman.2010.09.010

Koşan, A. (2013). Kış Sporları Turizmi-Kayak Turistlerinin Kış Turizm Merkezlerini Algı ve Değerlendirmelerine Ait Bir Araştırma (Palandöken'de Bir Uygulama). Atatürk Üniversitesi Sosyal Bilimler Enstitüsü Dergisi, 17(2), 293-324.

Kowal, J., \& Fortier, M. S. (1999). Motivational Determinants of Flow: Contributions from Self - Determination 
Theory. The Journal of Social Psychology, 139(3), 355-368. https://doi.org/10.1080/00224549909598391

Lekies, K. S., \& Yost, R. J. (2015) Urban Youth's Experiences of Nature: Implications for Outdoor Adventure Recreation Journal of Outdoor Recreation and Tourism, 9, 1-10 https://doi.org/10.1016/j.jort.2015.03.002

Lin, C. H., Sher, P. T., \& Shih, H. Y. (2005). Past Progress and Foture Directions İn Conceptualizing Customer Perceived Value. International Journal of Service Industry Management, 16(4), 318-336. https://doi.org/10.1108/09564230510613988

Matzler, K., Füller, J., Renzl, B., Herting, S., \& Späth, S. (2008). Customer Satisfaction with Alpine Ski Areas: The Moderating Effects of Personal, Situational, And Product Factors. Journal of Travel Research, 46(4), 403-413. https://doi.org/10.1177/0047287507312401

Matzler, K., \& Siller, H. J. (2003). Linking Travel Motivations with Perceptions of Destinations: The Case of Youth Travelers in Alpine Summer and Winter Tourism. Tourism Review, 58(4), 6-11. https://doi.org/10.1108/eb058418

McDougall, G. H., \& Levesque, T. (2000). Customer Satisfaction with Service: Putting Perceived Value İnto The Equation. Journal of Services Marketing, 14(5), 392-410. https://doi.org/10.1108/08876040010340937

Meydan, C. H., \& Şeşen, H. (2015). Yapısal Eşitlik Modellemesi AMOS Uygulamaları (2. Bask1, pp. 120-135). Detay Yayınc1lı, ISBN 978-605-5437-01-5. Ankara.

Murcia, J. A. M., Gimeno, E. C., \& Coll, D. G. C. (2008). Relationships Among Goal Orientations, Motivational Climate and Flow in Adolescent Athletes: Differences by Gender. The Spanish Journal of Psychology, 11(1), 181-191. https://doi.org/10.1017/S1138741600004224

Myers, D. G., \& Diener. E. (1995). Who is Happy? Psychological Science, 6(1), 10-19. https://doi.org/10.1111/j.1467-9280.1995.tb00298.x

Pain, M. T. \& Pain, M. A. (2005). Essay - Risk Taking in Sport. Lancet, 366. https://doi.org/10.1016/S0140-6736(05)67838-5

Palmer, A. (2001). Principles Services Marketing (3rd ed.). New York: McGraw - Hill Companies.

Parasuraman, A., Zeithaml, V. A., \& Berry, L. L. (1988). Servqual: A Multiple Item Scale for Measuring Consumer Perceptions of Service Quality. Journal of Retailing, 64, 12-40.

Pedersen, M. D. (1997). Perception of High-Risk Sport. Perceptual and Motor Skills, 85, 756-758. https://doi.org/10.2466/PMS.85.6.756-758

Petrick, J. F., \& Backman, S. J. (2002). An Examination of the Construct of Perceived Value for the Prediction of Golf Travelers' Intention to Revisit. Journal of Travel Research, 41, 38-45. https://doi.org/10.1177/004728750204100106

Priest, S., \& Gass, M. (2017). Effective Leadership in Adventure Programming (3rd ed.). Human Kinetics.

Puchan, H. (2004). Living 'Extreme': Adventure Sports, Media and Commercialisation. Journal of Communication Management, 9(2), 171-178. https://doi.org/10.1108/13632540510621588

Roberti, J. W. (2004). A Review of Behavioral and Biological Correlates of Sensation Seeking. Journal of Research in Personality, 38, 256-279. https://doi.org/10.1016/S0092-6566(03)00067-9

Rusting, C. L., \& Larsen, R. J. (1997). Extraversion, Neuroticism and Susceptibility to Positive and Negative Affect: A Test of Two Theoretical Models. Personality and Individual Differences, 22(5), 607-612. https://doi.org/10.1016/S0191-8869(96)00246-2

Sanchez, J., Callarisa, L., Rodriguez, R. M., \& Moliner, M. A. (2004). Perceived Value of the Purchase of a Tourism Product. Tourism Management, 27(3), 394-409. https://doi.org/10.1016/j.tourman.2004.11.007

Schermelleh, E. K., Moosbrugger, H., \& Müller, H. (2003). Evaluating the Fit of Structural Equation Models: Tests of Significance and Descriptive Goodness-of-Fit Measures. Methods of Psychological Research Online, 8(2), 23-74.

Şimşek, K. Y. (2010). Türk Ekstrem Sporcuları İçin Spor Tüketim Güdüsü Ölçeğinin Güvenirlik ve Geçerlik Çalışması. CBÜ Beden Eğitimi ve Spor Bilimleri Dergisi, 5(3), 97-106.

Şimşek, K. Y. (2012). Türk Ekstrem Sporcularının Spor Tüketim Faktörleri. Ege Akademik Baklş Dergisi, 12, $71-84$.

Slanger, E., \& Rudestam, K. E. (1997). Motivation and Disinhibition in High Risk Sports: Sensation Seeking 
and Self Efficacy. Journal of Research in Personality, 31, 335-374 https://doi.org/10.1006/jrpe.1997.2193

Teas K. R. (1993). Expectations, Performance Evaluation, and Consumers's Perceptions of Quality. Journal of Marketing, 57, 18-34. https://doi.org/10.1177/002224299305700402

Thomson, C. J. (2013). Seeking Sensations Through Sport: An Interdisciplinary Investigation of Personality and Genetics Associated with High-Risk Sport. Diss. University of British Columbia.

Thomson, C. J., \& Carlson, S. R. (2014). Personality and Risky Downhill Sports: Associations with Impulsivity Dimensions. Personality and Individual Differences, 60, 67-72. https://doi.org/10.1016/j.paid.2013.12.022

Thomson, C. J., Morton, K. L., Carlson, S. R., \& Rupert, J. (2012). The Contextual Sensation Seeking Questionnaire for Skiing and Snowboarding (CSSQ-S, pp. 503-521). https://doi.org/10.1037/t39573-000

Tomlinson, J., \& Leigh, E. (2004). Extreme Sports: In Search of the Ultimate Thrill. Firefly: Books Ltd.

Tsaur, S. H., Lin, W. R., \& Cheng, T. M. (2015). Toward A Structural Model of Challenge Experience in Adventure Recreation. Journal of Leisure Research, 47(3), 322-336. https://doi.org/10.1080/00222216.2015.11950363

Weinberg, R. S., \& Gould, D. (2011). Foundations of Sport and Exercise Psychology. Human Kinetic, 148-154.

Willig, C. (2008). A Phenomenological İnvestigation of The Experience of Taking Part in 'Extreme Sports'. Journal of Health Psychology, 13(5), 690-702. https://doi.org/10.1177/1359105307082459

Yapraklı, Ş., \& Sağlık, E. (2010). Hizmet İşletmelerinde Rekabet Aracı Olarak Hizmet Kalitesi ve İlişki Kalitesi: Konaklama İşletmelerinde Bir Uygulama. Öneri Dergisi, 9(34), 71-85.

Yavaş, Ö. (2017). Doğa ve Macera Rekreasyonu Katıllmcılarının Baskın Beyin Alanları, Aleksitimi ve Risk Alma Davranış İlişkisinin İncelenmesi. Yüksek Lisans Tezi. Manisa Celal Bayar Üniversitesi Sosyal Bilimler Enstitüsü.

Yıldız, S. M. (2009). Service Quality Models in Participant Sports Services. Ege Academic Review, 9(4), 12131224. https://doi.org/10.21121/eab.2009419673

Yücenur, G. N., Demirel, N. Ç., Cemil, C., \& Demirel, T. (2011). Measuring the Effects of Service Value on Behavioral Intentions with a Structural Equation Model. Doğuş Üniversitesi Dergisi, 12(1), 156-160. https://doi.org/10.31671/dogus.2019.158

Zeithaml, V. A., \& Bitner, M. J. (2000). Service Marketing (2nd ed.). McGraw Hill, Boston.

Zuckerman, M. (1979). Sensation Seeking: Beyond the Optimal Level of Arousal. Erlbaum: Hillsdale, NJ.

Zuckerman, M. (1994). Behavioral Expressions and Biosocial Bases of Sensation Seeking. New York: Cambridge University Press.

Zuckerman, M., \& Kuhlman, D. M. (2000). Personality and Risk Taking: Common Biosocial Factors. Journal of Personality, 68(6), 999-1029. https://doi.org/10.1111/1467-6494.00124

Zuckerman, M., \& Neeb, M. (1980). Demographic İnfluences in Sensation Seeking and Expressions of Sensation Seeking in Religion, Smoking and Driving Habits. Personality and Individual Differences, 1(3), 197-206. https://doi.org/10.1016/0191-8869(80)90051-3

\section{Copyrights}

Copyright for this article is retained by the author, with first publication rights granted to the journal.

This is an open-access article distributed under the terms and conditions of the Creative Commons Attribution license (http://creativecommons.org/licenses/by/4.0/). 